\title{
Growth of Sharing Economy in Hungary; Long Distance Car Sharing - A Case Study of Oszkár
}

\author{
Kinga Szabó ${ }^{1} \&$ Gauri Shankar Gupta ${ }^{2}$ \\ ${ }^{1}$ Doctoral School of Regional and Business Administration Sciences, Széchenyi István University Győr, Hungary \\ Correspondence: Gauri Shankar Gupta, Doctoral School of Regional and Business Administration Sciences, Széchenyi \\ István University Győr, Hungary. E-mail: gaurishankargupta@ yahoo.co.in
}

\author{
Received: April 23, 2020 Accepted: May 28, 2020 Online Published: June 9, 2020 \\ doi:10.5539/res.v12n3p9 URL: https://doi.org/10.5539/res.v12n3p9
}

\begin{abstract}
Rapid growth of sharing economy in the last two decades is the outcome of a paradigm shift in global capitalism and societal values. Based on digital identity and the Trust and Reputation Index, IT platforms have brought together strangers who under new social construct, share under-utilized capacities and assets with those who need them. Radius of trust which was initially confined to family and friends; now encompasses strangers who speak no common language and who live oceans apart. Hungary is no exception to this global shift. Sharing economy in Hungary has registered healthy growth specially in the areas of transportation and accommodation. Oszkár, a long-distance car-sharing company presents a good example of this paradigm shift in societal values and sharing with strangers. This platform has recorded impressive growth of over $67 \%$ between 2015-2018 with very positive customer reviews. Moreover, this represents an environmentally-friendly sustainable practice which successfully reduces carbon foot-print and traffic congestion.
\end{abstract}

Keywords: sharing economy, digital platform, radius of trust, Oszkár, long-distance car sharing

\section{Historical Perspective}

The concept of sharing economy is as old as human race. In the ancient time, there were many examples of sharing economy while hunting, fishing, farming and cooking. Subsequently these practices took the form of tribal or community behaviour and customs. In recent past, particularly after the Industrial Revolution; railways, public transport, hotels, public toilets, public libraries and collective farming are examples of such practices. However, the modern concept of sharing economy is based on sharing of private assets like apartments, cars, equipment and individual services and skills on an information technology (IT) platform. Rapid growth of IT and internet facilitated such platforms allowing strangers from across the world to have real time business interaction. Thus, currently, the sharing economy or collaborative economy is an umbrella term that covers online platforms that allows sharing of excess resources and assets such as office space, homes, goods, cars and even skills and knowledge (Hamari et al., 2016). With the rapid growth of information technology, evolution of new business models and change in social construct of ownership; individuals and groups are willing to share their assets for profit. Social media platforms like Facebook, WhatsApp, Trip Advisor and Pinterest, where people share ideas, information and insights also facilitate growth of sharing economy (Cusumano, 2014).

The concept of ownership of property and assets are becoming increasingly loose, porous and liquid. Social structure, institutions and values system have undergone radical change in the last few decades. Modernity, education, globalization and technology characterize the current social conditions that are increasingly unstable and are undergoing rapid change and therefore they cannot serve as frames of reference for human actions and long-term life strategies (Bauman, 2007). Increasingly, institutions, people, objects, information and places considered solid during the last century have tended to dematerialize and liquidize (Ritzer, 2010). Similarly, consumer identity and ethics are also becoming fluid and liquid. Social and individual values have been constantly undergoing change; due to urbanization, increasing anonymity and space constraints. Emotional, social and cultural ownership embedded in a property is becoming flexible, transient and liquid. Access to idle resources and assets has therefore, emerged as a way to manage the challenges of a liquid society. (Bardhi et al., 2012).

\section{Defining Sharing Economy}

While the term sharing economy is very popular and has been in use for over two decades, it still lacks a widely accepted, well-articulated, precise and comprehensive definition. Barter and swapping of goods, assets and services is an ancient practice. Before the advent of money (currency) as medium of exchange, there were physical markets for enabling barter of goods, assets and services. In a limited way the modern concept of sharing economy started with sharing of excess 
(both in terms of quantity and time) resources and assets on a digital platform. Strictly speaking sharing economy in the beginning was based on the consumer-to-consumer $(\mathrm{C} 2 \mathrm{C})$ or peer-to-peer $(\mathrm{P} 2 \mathrm{P})$ based activity of sharing access to individually owned goods and services where suppliers can connect buyers in virtual market places through IT based platforms. However, over time the concept expanded and now covers some elements of e-commerce including the bookings done through online market places. Thus, sharing economy is an economic model based on peer-to-peer activities on an IT based platform for providing or sharing access to excess of goods, assets and services. Applications like Uber, Airbnb and eBay are considered good examples of sharing economy.

In any sharing economy transactions generally, there are three factors; person, product and platform (3Ps). Of course, person is the most significant of the three as he/she is the decision maker and takes on the consequences. However, the platform that offers a product or service and the products and services offered are equally important. Digital identity of an entity or a platform or of an individual is the 'overall online footprint over a period of time'. Online reviews are considered as an important form of computer-mediated communication. Many academic experts describe the sharing economy as a growing ecosystem of online platforms and market places devoted to the exchange and renting of goods and services (Botsman \&Rogers, 2010; Hawlitschek et al. 2016; Lessig, 2008., Zervas et al. 2015). The traditional sharing, bartering, lending, trading, renting, gifting and swapping are redefined by using digital technology that is revolutionizing and mainstreaming the way people consume and share knowledge (Gata, 2015). Sharing economy is also called as access economy, collaborative economy, on-demand economy (Jaconi, 2014), platform economy or gig economy (Wilson, 2017). According to Investopedia; the sharing economy is an economic model defined as a peer-to-peer (P2P) based activity of acquiring, providing or sharing access to goods and services that is often facilitated by a community-based online platform (Investopedia, 2019). Thus, peer-to-peer business model providing temporary access to private resources of other individuals using real time IT platform is the fundamental characteristic of sharing economy. The economic transactions under this model are based on payment for one-time use or time-based rentals or fees and do not involve transfer of ownership. However, there are sharing economy platforms like eBay where ownership changes hands. Therefore, in this broader sense sharing economy implies a new economic model based on digitally-enabled, peer-to-peer platforms for goods and services that connect spare capacity of individuals with demand of those who need them and offer access by enabling renting, lending, swapping or even selling (Avital et al., 2015; Bardhi et al., 2012; Belk, 2009; Botsman \&Rogers, 2010; Möhlmann, 2015). The extensive penetration of information technology and peer-to-peer digital platforms in all spheres of human activities has created numerous options for online real time interaction and business transactions. It has transformed the way people think, live, eat, travel, shop, entertain and socialize. Considering the importance and social and economic impact of sharing economy, Rifkin described it as the third industrial revolution (Rifkin, 2011).

\section{Growth of Sharing Economy}

Historically, sharing was confined to family and friends. Due to lack of trust and privacy factors, people tended not to share with strangers and outsiders. During the last few decades more and more people have been moving to big cities, where the living and storage spaces are limited. This new life-style necessitated a shift in ownership, being able to access objects that are housed or stored elsewhere. Simultaneously, with increasing anonymity in an urban land-scape, the social status associated with ownership also underwent change. Growing environmental challenges, global economic crises, space constraints, increasing cost of holding idle assets, increased education, lack of resources to enable ownership, economy in expenditure, uncertainties in the labor market, rapid expansion of social media and public willingness to trust and share are other important factors that have led to the rapid growth of sharing economy (Hira \& Reilly, 2017; Hamari et al., 2016). Growth of efficient IT enabled platforms and effective online rating systems reduced fears substantially and enabled sharing among strangers who do not know each other, do not speak the same language, have never met and are unlikely to ever meet. Today, people share their private cars with strangers, eat food cooked and transported by strangers and allow strangers to live in their apartments which was inconceivable a few decades ago. Digital platforms, digital identity (DI) and User Generated Contents (UGC) and the Trust and Reputation Index (TRI) based on well-designed rating systems have enhanced the radius of trust making sharing less risky and more acceptable with strangers. These IT devices and applications have given birth to services like Airbnb, Car2Go, DriveNow, Uber, Ola, Oszkár, Zipcar, Blablacar and so on. In recent years, even the large companies like BMW, MOL and AUDI have launched their own sharing platforms as they find them attractive, sustainable and business friendly.

Thus, powered by efficient digital platforms, willingness of consumers to try mobile applications that facilitate peer-to-peer business models, shared IT-based enterprises, digital identity and TRI, efficient and rapid digital payment systems and changing social concept of ownership of assets sharing economy has registered a spectacular growth during the last two decades. Given the current global trends towards sharing of assets, sharing economy will inevitably become a major part of the global economy in the coming decades. According to an article published by the Brookings Institution, the sharing economy is estimated to grow from $\$ 14$ billion in 2014 to $\$ 335$ billion by 2025 (Niam \& Shamika, 2017). This 
estimate is based on the rapid growth of Uber and Airbnb. According to the "Share Economy 2017" report based on a study in selected European countries by the PricewaterhouseCoopers (PWC), the following is the average frequency of share economy usage per year within different industry segments (PWC Share Economy, 2017). According to PWC, 275 companies were operating in Europe in sharing economy in 2017.

Table 1. Average Sharing Economy Usage within the Different Industry Segments by Users

\begin{tabular}{|c|c|}
\hline Media and Entertainment & $33.3 \%$ \\
\hline Transport & $9.5 \%$ \\
\hline Retail and Consumer Goods & $8.6 \%$ \\
\hline Machinery & $5.6 \%$ \\
\hline Finance & $5.4 \%$ \\
\hline Accommodation & $5.0 \%$ \\
\hline Services & $4.9 \%$ \\
\hline
\end{tabular}

Source: PWC. Share Economy, New Business Model, at https://www.pwc.de/de/digitale-transformation/share-economy-report-2017.pdf

Expansion of mobility-sharing has been the fastest of all segments of sharing economy followed by accommodation and tourism. Today, there are host of such companies spanning over all the continents. These include Uber, Ola, Oscar, BlaBlaCar, VULOG, MOMO Carsharing and Zipcar in addition to the traditional car rental companies like Hertz, Europcar, Sixt, Avis, Rent a Car and so on. Expected growth of global carsharing services are given below in a chart obtained from Statista. According to a study undertaken by Shaheen and Cohen, global carsharing growth has been impressive (Shaheen \& Cohen, 2016). As of October 2014, carsharing was operating in 33 countries in 5 continents and in about 1530 cities with approximately 4.8 million members sharing more than 104.000 vehicles. The following chart provides the projected growth of the global carsharing services.

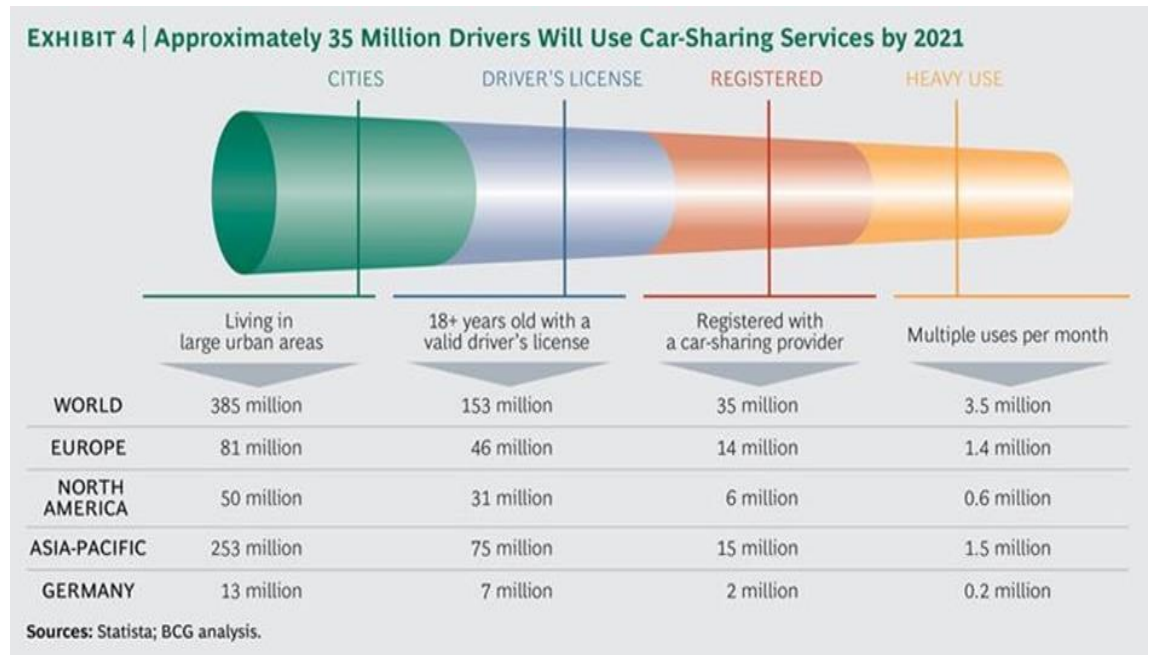

Figure 1. Expected Growth of Global Carsharing Services by 2021

Source: The Boston Consulting Group, 2016. What's Ahead for Car Sharing? The New Mobility and Its Impact on Vehicle Sales, retrieved from https://image-src.bcg.com/Images/BCG-Whats-Ahead-for-Car-Sharing-Feb-2016_tcm9-64441.pdf

\section{Contours of Sharing Economy in Hungary}

Renting out a cottage at Lake Balaton and Mátra Mountains, the most popular summer holiday destinations for foreigners, time sharing at baths and spa, taking tourists from the airport to hotels and sale and exchange of used goods were common in Hungary; even before online platforms came to exist. In the modern context, Uber was one of the first mobility-sharing service introduced in Budapest. However, due to protest by taxi drivers and stiff regulations governing Hungarian taxi services, Uber was soon banned. All this happened shortly after the company had managed to sign up more than 160,000 customers and 1,200 drivers by mid-2016, following its November 2014 launch. According to Euromonitor International, Airbnb short-term accommodation rental service, is fairly popular among foreign tourists coming to Hungary, who prefer to stay in apartments at economic prices. Currently, over 8,000 apartments are listed on Airbnb, mostly concentrated in Budapest. This represents approximately a fifth of all short-term rental outlets in Hungary, which are serving tourists at popular holiday and spa destinations, but other popular destinations across the country are also catching up (Euromonitor International, 2019). A survey conducted by the authors, revealed the following details of the sharing economy in Hungary in mobility sector. 
The Hungarian Oil Corporation (MOL), an MNC started a bike-sharing enterprise called MOL Bubi on $8^{\text {th }}$ September 2014 to promote environmental consciousness. As of $10^{\text {th }}$ of May 2019, there were 143 docking stations with 1846 bikes in Budapest where the bikes could be picked up and dropped. A MOL Bubi user can buy a 24-hour, 72-hour or weekly ticket or a quarterly, semi-annual or annual pass by paying the access fee to the public bike-sharing system. Those who have a MOL Bubi ticket or pass, the first 30 minutes of each of the rides are free of charge. Bike can be picked up from any docking station with the help of the terminal or the sensor on the rear-side of the bike or by using the MOL Bubi mobile app.

GreenGo is the first e-carsharing service in Budapest that started its operation in November 2016 with 45 cars. By October 2018 the number of cars went up to 270. As of September 2019 GreenGo, had a fleet of over 300 cars in Budapest. GreenGo provides environmentally friendly electric vehicles, with green licence plates. Following the online registration procedure one can access the GreenGo cars with the help of a smartphone application available for iOS and Android. Cars are available 24/7, without any contract and there is no handover of keys either. Payment is automatically charged to the bank card and the invoices are sent out electronically. The charges are all inclusive; user fee, refuelling, parking and maintenance. The customer can find the location of the nearest car on the online application and leave the car at any public parking place within Pest County after its use.

MOL LIMO a car renting service was started by MOL on $29^{\text {th }}$ January 2018. Following the registration, MOL LIMO could be accessed through an application 24/7. LIMO zone covers inner districts of Budapest. Currently MOL LIMO offers 450 cars; 20 electric Smart EQ ( 2 seater), 30 electric Smart EQ (4 seater), 100 electric Volkswagen eUp!s, 250 gas-powered Volkswagen Up!s and 50 Mercedes-Benz A-Class. Anyone over 18 years of age who possesses a valid category B driving licence for at least a year and registers him or herself can access the car through LIMO app. The service is available on the basis of per minute fee with or without monthly fee. The time -based fee includes all costs including; user fee, refuelling, parking and maintenance costs. There are no designated stations for MOL LIMO. The user can leave the car in any public parking space within the Limo zone without paying for it. The payments are automatically deducted from the registered debit or credit card.

DriveNow is a car sharing service wholly owned by the automotive manufacturer BMW. DriveNow service began in Munich, Germany in June 2011. DriveNow Hungary, a locally registered company, launched an application-based car sharing service in Budapest on April 29, 2019 with 240 vehicles. The service cover 63 square kilometres in and around Budapest. Rental fee is charged by the minute with the option of daily and three, six, and nine-hour passes. The cars available in Hungary mainly consist of Minis and BMW i3, X2 and series 1 models. The cars are accessible via the DriveNow application available for iOS and Android.

There are no other public car sharing services in Hungary apart from those listed above and Oszkár which is a long-distance car sharing service which has been covered in detail in the subsequent section. However, German car manufacturer Audi has a car sharing service called Audi 1.2 GO specially designed for its employees for their official movement within the areas of company's operations. This has been specially designed as a perquisite to facilitate the movement of Audi employees and to earn their loyalty. This service is not available to public.

\section{Oszkár, Hungary- A Case Study}

Oszkár is one of the largest sharing-economy platforms in Hungary. While the company is known as Oszkár in Hungary, international brand name of the company is Motar, which stands for "More Than a Ride". This platform connects on real time basis, long distance drivers with empty seats in their cars with the passengers who are looking for rides on the identical routes. As part of our research on Oszkár, we met some responsible officers and the Managing Director of the company to find out their operational details. Separately, we did a passenger satisfaction survey in the form of interviews with Oszkár car-sharing passengers on selected routes. (Since these surveys were confidential in nature, we are not in a position to disclose their names). The following details are based on these two surveys.

Oszkár provides IT platform for long distance car-sharing services from one city to another primarily within Hungary but also to some destinations in Austria like Vienna. Legally speaking, the company only expects passengers to share the cost with the driver and does not offer regular transportation services. The passengers who decide to travel using Oszkár platform, travel at their own risk. Precisely because of this legal status Oszkár could survive in 2016 when the Government of Hungary tightened the legal environment for personal transport services in the country. On the other hand, Uber which was considered as a company offering regular transport services on its platform, could not survive due to new regulatory environment. This led to the closure of Uber in Hungary in 2016. Attila Prácser and Máté Gyürüs both former students at the Budapest University of Technology and Economics in the faculty of Transportation Engineering are the co-founders of the company. They conceived, designed and launched this platform in November 2007 in a very limited way. In the beginning, both the co-founders performed everything themselves; from planning, launch of the IT platform, technical services and marketing. Subsequently, Maté specialised in technical services and became Chief Technical 
Director while Attila took over as Managing Director and the company started offering services on multiple routes with higher frequency.

The principal stated aim of the company is to provide travel-mates for drivers on the road who are driving alone and who want to reduce their cost or to have a companion on the route in order to perform a pleasant trip. For passengers, it offers a more economic, faster and more flexible way of travelling. In other words, it's a car-pool or ride-sharing service whereby drivers and passengers are brought together on the same platform. Passengers are picked up either at a designated pick-up point or at the location mutually agreed by them and are dropped either at a pre-determined point or at their final destination. IT platform - Android, iOS and web applications - provides a way for drivers and passengers to find each other on real time basis. Passengers are given driver's contact number while the drivers are provided passengers' contact details to facilitate direct contact between them to avoid any confusion or delay. In case of any unexpected problem, they also have access to the customer service provided by the company.

Given the flexibility of pick-up and drop locations, the multiple timings of the services, reduced travel time and the substantially lower cost of travel; the company has expanded considerably during the last six years from 2014-2019. Since the long-distance train and bus services operate as per fixed schedules, passengers have to wait and adjust their schedule accordingly. Moreover, in case of change in passengers' programme, they are obliged to lose the entire cost of their ticket. On the other hand, one can find ride sharing on Oszkár on several times a day. This allows passengers to save time with no idle waiting. Similarly, many times Oszkár services pick-up passengers right from their homes/offices or nearby locations and drop them close to their destinations. This not only saves time but also the cost of hiring taxies both at the origin and at the destination. Since the cost of car-sharing varies frequently, sometimes even on daily basis, it is not possible to compare the cost of car-sharing with the regular fares by trains and long-distance buses. Nevertheless, in most cases the cost of car-sharing compares favourably with the cost of travel by trains and buses. Moreover, in case of cancellation of a trip, the passenger normally does not lose any money. More importantly, in this era of environmental degradation and climate change, car-sharing is environmentally friendly. This is an effective method of reducing $\mathrm{CO} 2$ emissions and congestion on roads and highways. This practice also helps in reducing traffic congestions in cities particularly in city centres making parking space more accessible and traffic movement faster. Because of these obvious advantages, the Oszkár car-sharing services have been gaining in popularity every passing day. A passenger satisfaction survey conducted by us spreading over three-year period is given below in two tables. The first table lists 22 drivers and number of passengers and kilometres covered by them. The second table provides details of the customer ratings for these drivers.

Table 2. Oszkár Drivers and Number of Passengers and Kilometers Covered

\begin{tabular}{|c|c|c|c|}
\hline Name & Number of rides & Travelled passangers & Travelled km on Oszkár \\
\hline Judit777 & 209 & 534 & $43587 \mathrm{~km}$ \\
\hline István & 296 & 659 & $79391 \mathrm{~km}$ \\
\hline Zsike53 & 151 & 342 & $41075 \mathrm{~km}$ \\
\hline Nandika26 & 332 & 1387 & $79836 \mathrm{~km}$ \\
\hline Optim Trans Bus Kft & 9122 & 12580 & $2592614 \mathrm{~km}$ \\
\hline Judit & 130 & 261 & $28331 \mathrm{~km}$ \\
\hline Péter & 491 & 2822 & $151411 \mathrm{~km}$ \\
\hline Tamás & 263 & 506 & $97093 \mathrm{~km}$ \\
\hline György & 2227 & 3198 & $531063 \mathrm{~km}$ \\
\hline Endre & 335 & 965 & $76768 \mathrm{~km}$ \\
\hline PajtiKG0 & 158 & 319 & $44483 \mathrm{~km}$ \\
\hline Zoltán & 1498 & 7860 & $325518 \mathrm{~km}$ \\
\hline Hanna & 31 & 43 & $3757 \mathrm{~km}$ \\
\hline Ivanho & 133 & 483 & $31097 \mathrm{~km}$ \\
\hline Laszlo & 219 & 842 & $66507 \mathrm{~km}$ \\
\hline Roland79 & 7102 & 8181 & $6964839 \mathrm{~km}$ \\
\hline plaszlo90 & 1337 & 8081 & $310966 \mathrm{~km}$ \\
\hline Oliver & 251 & 433 & $95834 \mathrm{~km}$ \\
\hline Janos & 32 & 31 & $13117 \mathrm{~km}$ \\
\hline Norbert & 96 & 165 & $21021 \mathrm{~km}$ \\
\hline Bea & 26 & 55 & $5622 \mathrm{~km}$ \\
\hline Mirko & 258 & 492 & $50783 \mathrm{~km}$ \\
\hline
\end{tabular}

Source: Oszkár platform, Hungary at oszkar.com 
Table 3. The Customer Ratings for Drivers

\begin{tabular}{|c|c|c|c|c|c|c|c|}
\hline Name & $\begin{array}{c}\text { Evaluation by } \\
\text { passangers }\end{array}$ & Point + & $\begin{array}{c}\text { Point } \\
\text { neutral }\end{array}$ & $\begin{array}{c}\text { Point } \\
\text { minus }\end{array}$ & $\begin{array}{c}\text { Final } \\
\text { evaluation }\end{array}$ & $\begin{array}{c}\text { Answer } \\
\text { messages }\end{array}$ & $\begin{array}{c}\text { Time } \\
\text { answering messages }\end{array}$ \\
\hline Judit777 & 357 & 355 & 1 & 1 & 5 & $100 \%$ & within few minutes \\
\hline István & 405 & 401 & 2 & 2 & 5 & $100 \%$ & within few minutes \\
\hline Zsike53 & 214 & 212 & 1 & 1 & 5 & $100 \%$ & within few minutes \\
\hline Nandika26 & 727 & 726 & 0 & 1 & 5 & $75 \%$ & within few minutes \\
\hline Optim Trans Bus Kft & 5231 & 5132 & 76 & 23 & 5 & $99 \%$ & within few minutes \\
\hline Judit & 137 & 137 & 0 & 0 & 5 & $100 \%$ & within few minutes \\
\hline Péter & 1036 & 1022 & 11 & 3 & 5 & $100 \%$ & within few minutes \\
\hline Tamás & 282 & 279 & 1 & 2 & 5 & $100 \%$ & within few minutes \\
\hline György & 1309 & 1275 & 17 & 17 & 4.8 & $92 \%$ & 3hours \\
\hline Endre & 502 & 498 & 4 & 0 & $4 . .9$ & $100 \%$ & within few minutes \\
\hline PajikG0 & 182 & 182 & 0 & 0 & $4 . .9$ & $100 \%$ & within few minutes \\
\hline Zoltán & 12723 & 12685 & 27 & 11 & 5 & $100 \%$ & within few minutes \\
\hline Hanna & 186 & 184 & 2 & 0 & $4 . .9$ & $100 \%$ & within few minutes \\
\hline Ivanho & 238 & 236 & 2 & 0 & 4.9 & $100 \%$ & within few minutes \\
\hline Laszl0 & 356 & 350 & 1 & 5 & 4.6 & $73 \%$ & within few minutes \\
\hline Roland79 & 2516 & 2379 & 80 & 55 & $4 . .8$ & $93 \%$ & within few minutes \\
\hline plaszl090 & 3597 & 3591 & 3 & 2 & 5 & $88 \%$ & 3hours \\
\hline Oliver & 216 & 200 & 2 & 14 & $4 . .1$ & $100 \%$ & within few minutes \\
\hline Janos & 17 & 17 & 0 & 0 & 5 & $100 \%$ & within few minutes \\
\hline Norbert & 183 & 181 & 1 & 1 & $4 . .8$ & $100 \%$ & within few minutes \\
\hline Bea & 36 & 34 & 0 & 0 & 5 & $100 \%$ & within few minutes \\
\hline Mirk0 & 273 & 269 & 2 & 2 & 5 & $86 \%$ & 2 hours \\
\hline
\end{tabular}

Source: Oszkár platform, Hungary at oszkar.com

From the tables given above, it is clear that except in one case, all the drivers have been evaluated between 4.8 and 5 on the scale of 5. This clearly indicates very high passenger satisfaction level. Similarly, except in two cases, messages from the passengers have been answered within a few minutes. Obviously, this means that the services at the platform are highly efficient and prompt. Moreover, there was no particular complaint regarding the conduct of drivers. No instance of accident was reported to us during the survey. The regular ratings provided to the drivers as also to the passengers works as safety net both against the rash drivers as also against the unruly passengers. While drivers can refuge to take unruly passengers, the passengers can avoid the drivers with poor ratings. Since the passenger satisfaction is fairly high, the demand for the car-sharing service at the platform are rising regularly. Hence the carpooling platform - Oszkár - genuinely benefits both the drivers and the passengers and provides a sensible option. By allowing drivers to off-set the cost of travelling, Oszkár has been able to avoid the criticisms aimed at companies in the sharing economy that appear to encourage unregulated and unfair practices.

This expansion has been clearly reflected in terms of the swelling driver and passenger numbers, expansion of operating routes and the operating staff of the company. The following table provides the details of the growth of number of drivers and passengers during 2015-2018.

Table 4. Details of the Growth of Number of Drivers and Passengers During 2015-2018

\begin{tabular}{|c|c|c|c|c|c|c|}
\hline Year & \multicolumn{3}{|c|}{ Drivers } & & Passengers & \\
\hline & Male & Female & Total & Male & Female & Total \\
\hline & & & & & & \\
\hline $\mathbf{2 0 1 5}$ & 21921 & 5262 & 27183 & 290469 & 53582 & 344051 \\
\hline & & & & & & \\
\hline $\mathbf{2 0 1 6}$ & 26063 & 6282 & 32345 & 272997 & 70178 & 343175 \\
\hline & & & & & & \\
\hline $\mathbf{2 0 1 7}$ & 30253 & 7429 & 37682 & 450559 & 85102 & 535661 \\
\hline & & & & & & \\
\hline $\mathbf{2 0 1 8}$ & 32064 & 7832 & 39896 & 484774 & 90619 & 575393 \\
\hline
\end{tabular}

Source: Attila Prácser, Managing Director Oszkár, Hungary 
From the above table it is clear that during 2015 to 2018 the company recorded a passenger growth of $67.24 \%$ while the number of drivers grew at $46.76 \%$. These are indeed impressive figures. Moreover, the growth both in male and female segments under both the categories - drivers and passengers - has been in consonance with the overall growth. In fact, a close study of these data reveals, that the growth of female participation under both the categories has been slightly higher than in male participation. The number of male drivers increased by $46.27 \%$ while the female drivers recorded a growth of $48.84 \%$. The number of male passengers increased by $66.89 \%$ while the female passengers recorded a growth of $69.12 \%$. This is a clear indication of the confidence reposed by female drivers and passengers in the operations of the company. Although in a large majority of cases the Oszkár services operate on genuine car sharing basis, in some cases drivers do operate their vehicles primarily to transport their passengers as is done by a public transport company. However, to completely eliminate such practices is extremely difficult as there will always be some drivers who buy their vehicles primarily to transport passengers under Oszkar platform. It is almost impossible to establish genuineness of all drivers operating on a route. There are 134,000 followers on the Facebook of Oszkár. In addition, the company also has a sizeable following on Instagram.

According to the statistics provided for the second half of 2018, the following were the most popular routes for travel by Oszkár passenger sharing transport within Hungary. Although the relative popularity of the long-distance routes has changed marginally, the 20 routes given below have remained the most popular ever since 2015 .

Table 5. The Most Popular Routes for Oszkár Passenger Sharing Transport within Hungary

\begin{tabular}{|c|c|c|c|}
\hline & Long-distance Route & Fare HUF & No. of Passengers \\
\hline 1 & PÉCS-BUDAPEST & 2480 & 31581 \\
\hline 2 & SZEGED-BUDAPEST & 1960 & 30584 \\
\hline 3 & DEBRECEN-BUDAPEST & 2580 & 28277 \\
\hline 4 & MISKOLC-BUDAPEST & 2060 & 26020 \\
\hline 5 & NYÍREGYHÁZA-BUDAPEST & 2800 & 20436 \\
\hline 6 & KECSKEMÉT-BUDAPEST & 1070 & 7660 \\
\hline 7 & KAPOSVÁR-BUDAPEST & 2360 & 7444 \\
\hline 8 & BUDAPEST-SZOMBATHELY & 2770 & 6643 \\
\hline 9 & GYÕR-BUDAPEST & 1580 & 5988 \\
\hline 10 & NAGYKANIZSA-BUDAPEST & 2630 & 5863 \\
\hline 11 & EGER-BUDAPEST & 1630 & 5594 \\
\hline 12 & BAJA-BUDAPEST & 2190 & 5092 \\
\hline 13 & BUDAPEST-GYÖR & 1580 & 5086 \\
\hline 14 & BUDAPEST-SIÓFOK & 1510 & 5051 \\
\hline 15 & ZALAEGERSZEG-BUDAPEST & 2690 & 4456 \\
\hline 16 & BUDAPEST-VESZPRÉM & 1520 & 4113 \\
\hline 17 & BÉCS-BUDAPEST & 3580 & 3793 \\
\hline 18 & SOPRON-BUDAPEST & 2550 & 3131 \\
\hline 20 & MÁTÉSZALKA-BUDAPEST & 3610 & 2935 \\
\hline
\end{tabular}

Source: Attila Prácser, Managing Director Oszkár, Hungary

According to the company officials at least 400,000 people use Oszkár at least once a year. Total users of Oszkár car-sharing services until 2019 were expected in the range of 775,000 with 6.5 million rides. In 2019, alone 135,000 new users were added to the platform. These statistics also indicate that on an average each passenger has taken 8.39 rides on Oszkár. Since the passengers have been using this platform frequently, it is apparent that they are satisfied with the services. Daily usage varies considerably between normal week-days, Fridays and week-ends as also the seasons of the year. Maximum usage has been recorded in summer months during the week-ends. As of November 2019, the company had a dedicated marketing and customer service team of six people plus four others who were handling customer services outside of normal working hours. It is therefore clear that rising popularity of long-distance car sharing services in Hungary have contributed to the rapid growth of Oszkár.

\section{Conclusion}

During the last two decades sharing economy has re-written the rules of the traditional economic system. Individuals and families have come forward to share their private assets and resources with strangers which was inconceivable some years ago. Digital platforms have facilitated real time interaction cutting across time and space barriers. Well-designed online reviews and Trust and Reputation Index have enhanced the radius of trust towards strangers. Change in social construct, 
growing anonymity in urban landscape, economic sustainability, growth of IT platforms and expanding radius of trust has led to spectacular growth of sharing economy in the last two decades. Hungarian economy is also experiencing rapid growth of sharing economy particularly in the field of transportation and accommodation. Oszkár a long-distance car sharing enterprise is a successful example in this sector. Its growth has been spectacular since 2014 and the customer satisfaction level is fairly high. Both the drivers and the passengers have benefitted from Oszkár as outlined above. For drivers it's a source of additional income and pleasant company on the long-distance trips while passengers save on their cost and time with more flexible pick-up and drop-points. Moreover, this represents an environmentally friendly sustainable economic model which has successfully reduced the carbon foot-print and congestion of vehicles on roads. However, a regulatory framework for such ride-sharing companies, safety of passengers and accountability of drivers are some of the issues that need to be addressed in the years ahead.

P.S. The current extraordinary situation resulting due to Covid19 pandemic is likely to impact global polity, society and economy in a profound way. Obviously, these profound changes can also re-write the parameters and the rules of the sharing economy in the future.

\section{References}

Avital, M., Carroll, J. M., Hjalmarsson, A., Levina, N., Malhotra, A., \& Sundararajan, A. (2015). The Sharing Economy: Friend or foe? Paper presented at the 36th International Conference on Information Systems, Fort Worth, TX.

Bardhi, F., Eckhardt, G. M., \& Arnould, E. J. (2012). Liquid Relationship to possessions. Journal of Consumer Research, 39(3). https://doi.org/10.1086/664037

Bauman, Z. (2007). Liquid Times: Living in an Age of Uncertainty. Cambridge: Polity. https://doi.org/10.1086/664037

Belk, R. (2010). Sharing. Journal of consumer research, 36(5), 715-734. https://doi.org/10.1086/612649

The Boston Consulting Group - Bert, J., Collie, B., Gerrits, M., \& Xu, G. (2016). What's Ahead for Car Sharing? The New Mobility and Its Impact on Vehicle Sales. Retrieved from https://image-src.bcg.com/Images/BCG-Whats-Ahead-for-Car-Sharing-Feb-2016_tcm9-64441.pdf

Botsman, R., \& Rogers, R. (2010). What's Mine Is Yours: The Rise of Collaborative Consumption, New York: HarperCollins.

Cusumano, M. A. (2014). How traditional firms must compete in the sharing economy. Communications of the ACM, 58(1), 32-34. https://doi.org/10.1145/2688487

Euromonitor International. (2019). Hungary: The Painful Birth of the Sharing Economy. Retrieved from https://blog.euromonitor.com/hungary-the-painful-birth-of-the-sharing-economy/

Gata, J. (2015). The Sharing Economy, Competition and Regulation. Competition Policy International Retrieved from https://www.competitionpolicyinternational.com/the-sharing-economy-competition-and-regulation/

Hawlitschek, F., Teubner, T., Adam, M. T. P., Borchers, N. S., Moehlmann, M., \& Weinhardt, C. (2016). Trust in the sharing economy: An framework. Rerimental Retrieved from https://www.scopus.com/inward/record.uri?eid=2-s2.085019453377\&partnerID=40\&md5=078cfb694febff08b8440bca530a48e 5

Hamari, J., Sjöklint, M., \& Ukkonen, A. (2016). The sharing economy: Why people participate in collaborative consumption. Journal of the Association for Information Science and Technology, 67(9), 2047-2059. https://doi.org/10.1002/asi.23552

Hira, A., \& Reilly, K. (2017). The Emergence of Sharing Economy: Implications for Development. Journal of Developing Societies, 33(5). https://doi.org/10.1177/0169796X17710071

Investopedia (2019). What is the Sharing economy? Retrieved from https://www.investopedia.com/terms/s/sharing-economy.asp

Jaconi, M. (2014). The 'On-Demand Economy' Is Revolutionizing Consumer Behavior - Here's How. Business Insider. Retrieved from http://www.businessinsider.com/the-on- demand-economy-2014-7

Lessig, L. (2008). Remix-Making art and commerce thrive in the hybrid economy. New York, NY: Penguin Press. https://doi.org/10.5040/9781849662505

Möhlmann, M. (2015). Collaborative consumption: Determinants of satisfaction and the likelihood of using a sharing economy option again. Journal of Consumer Behaviour, 14(3), 193-207. https://doi.org/10.1002/cb.1512

Rifkin, J. (2011). The Third Industrial Revolution. New York, NY: Palgrave MacMillan.

Ritzer, G. (2010). Sociological Theory. New York, NY: McGraw-Hill. 
PWC. Share Economy, New Business Model. (2017). Retrieved from: https://www.pwc.de/de/digitale-transformation/share-economy-report-2017.pdf

Shahen, S., \& Cohen, A. (2016). Innovative mobility carsharing outlook: Carsharing market overview, analysis, and trends: $\quad$ Winter $2016 . \quad$ Retrieved from: http://innovativemobility.org/wp-content/uploads/2016/02/Innovative-Mobility-Industry-Outlook_World-2016-Fin al.pdf

Niam, Y., \& Shamika, R. (2017). The Current and Future State of the Sharing Economy. Brookings India IMPACT $\begin{array}{lllll}\text { Series No.032017 } & \text { March } & \text { Retrieved from: }\end{array}$ https://www.brookings.edu/wp-content/uploads/2016/12/sharingeconomy_032017final.pdf

Wilson, B. (2017). Business Reporter. What is the 'gig' economy? (BBC News) Retrieved from http://www.bbc.com/news/business-38930048 (Accessed on 20 September, 2019)

Zervas, G., Proserpio, D., \& Byers, J. (2015). A first look at online reputation on Airbnb, where every stay is above average. https://doi.org/10.2139/ssrn. 2554500

\section{Copyrights}

Copyright for this article is retained by the author(s), with first publication rights granted to the journal.

This is an open-access article distributed under the terms and conditions of the Creative Commons Attribution license (http://creativecommons.org/licenses/by/4.0/). 